\title{
SISTEM INFORMASI UJIAN MASUK PERGURUAN TINGGI DENGAN PELAYANAN ONE DAY SERVICE BERBASIS ONLINE (STUDI KASUS DI UNIVERSITAS MUHAMMADIYAH SORONG)
}

\author{
Rendra soekarta ${ }^{1}$,Eri Fridayanti ${ }^{2}$ \\ ${ }^{1,2}$ Fakultas Teknik Program Studi Teknik Informatika Universitas Muhammadiyah Sorong
}

\begin{abstract}
Muhammadiyah Sorong University is the only private university owned by Persyarikatan Muhammadiyah in Sorong City, West Papua Province. Every year the Muhammadiyah University Campus organizes Higher Education Entrance Test. In the initial system the implementation of Exams for New Student Candidates at the Muhammadiyah Sorong University Campus is still manual, still using paper, stationery and still requires a lot of time in working on the questions and the results of the determination of majors based on test scores are still announced on the bulletin board. The purpose of this study is to create an information system that can be used to facilitate the examination committee in the examination, correcting answers, determine the value and determination of majors for prospective students based on the results of exam results and reduce the estimated time in working on exam questions. software development with the stages of Requirement Analysis, System Design, Implementation (coding), Testing, Implementation and Maintenance of Systems. This exam information system is built using the programming language PHP 5.6.31 d and MySQL 4.8.2. Then the Database Design uses UML and ERD. Implementation of this Exam Information System includes Examination, Question Making, Exam Participant Data and Prospective Participants can find out the value of the test results and Determination pass to the majors based on the acquisition of test scores.
\end{abstract}

Keywords: Exam Information System Online, Waterfall, PHP, Mysql.

\begin{abstract}
Abstrak
Universitas Muhammadiyah Sorong merupakan satu-satunya Universitas swasta milik Persyarikatan Muhammadiyah yang berada di Kota Sorong Provinsi Papua Barat. Pada setiap tahunya Kampus Universitas Muhammadiyah menyelenggarakan Ujian Tes Masuk Perguruan Tinggi. Pada sistem awal pelaksanaan Ujian bagi Calon Mahasiswa Baru di Kampus Universitas Muhammadiyah Sorong masih secara manual, masih menggunakan kertas, alat tulis dan masih memerlukan waktu yang banyak dalam mengerjakan soal serta hasil penentuan jurusan berdasarkan nilai ujian masih di umumkan di papan pengumuman. Tujuan penelitian ini adalah membuat sistem informasi yang dapat digunakan untuk memudahkan panitia ujian dalam pelaksanaan ujian, pengoreksian jawaban, menentukan nilai serta penentuan jurusan bagi calon mahasiswa berdasarkan nilai hasil ujian dan mengurangi estimasi waktu dalam pengerjaan soal ujian.Penelitian ini dilakukan dengan menggunakan metode Waterfall untuk pengembangan perangkat lunak dengan tahapan Analisis Kebutuhan, Desain Sistem, Implementasi (coding), Pengujian, Penerapan dan Pemeliharaan Sistem. Sistem Informasi ujian ini di bangun menggunakan Bahasa Pemograman PHP 5.6.31 d dan MySql 4.8.2. Kemudian Perancangan Database menggunakan UML dan ERD . Implementasi Sistem Informasi Ujian ini meliputi Pengerjaan Ujian, Pembuatan Soal, Data Peserta Ujian dan Calon Peserta dapat mengetahui nilai hasil ujian dan Penentuan lulus ke jurusan berdasarkan perolehan nilai ujian.
\end{abstract}

Kata Kunci: Sistem Informasi Ujian Online, Waterfall, PHP, Mysql

\section{Pendahuluan}

\subsection{Latar Belakang}

Universitas Muhammadiyah Sorong merupakan salah satu perguruan tinggi yang berada di Kota Sorong Papua Barat yang meyelenggarakan penerimaan mahasiswa baru dan juga Ujian tes Akademik setiap tahunnya.Penerapan teknologi dan sistem informasi dalam proses ujian bagi calon mahasiswa baru dikampus Universitas
Muhammadiyah Sorong masih secara manual seperti, masih menggunakan kertas yang dapat mengakibatkan pemborosan dalam penggunaanya, masih menggunakan alat tulis seperti pena, penghapus dan alat tulis lainnya.

Masalah yang muncul dalam proses ujian seleksi calon mahasiswa baru yang masih secara manual yaitu resiko berkas ujian menumpuk sehingga keputusan Mahasiswa pun bisa tidak efektif, terjadi kesalahan pada saat pemeriksaan hasil ujian, memerlukan banyak 
waktu saat pengoreksian hasil ujian, mengurangi terjadinya kesalahan aturan dalam pengisian jawaban oleh calon mahasiswa, seperti memilih lebih dari satu jawaban.

Dari permasalahan diatas maka penulis merasa tertarik melakukan penelitian lebih lanjut dengan judul "Sistem Informasi Ujian Masuk Perguruan Tinggi dengan Pelayanan One Day Service Berbasis Online (Studi Kasus di Universitas Muhammadiyah Sorong)”.

\subsection{Rumusan Masalah}

Berdasarkan latar belakang diatas maka dirumuskan permasalahan penelitian sebagai berikut :

1. Bagaimana cara merancang sistem informasi Ujian masuk Perguruan Tinggi dengan pelayaanan One Day Service bagi Calon Mahasiswa Baru di Kampus Universitas Muhammadiyah Sorong yang dapat menyelesaikan kesalahan pada pemeriksaan ujian, memerlukan banyak waktu dalam pengoreksian, mengurangi terjadinya kesalahan dalam pengisian jawaban?

2. Bagaimana cara menerapkan Ujian Masuk Perguruan Tinggi kepada Calon Mahasiswa Baru dengan pelayanan One Day Service di Kampus Universitas Muhammadiyah Sorong?

\subsection{Maksud Dan Tujuan Penelitian}

1. Dapat membuat sistem yang dapat memudahkan bagi Panitia Ujian dalam melaksanakan Ujian Online bagi calon Mahasiswa baru di Kampus Universitas Muhammadiyah Sorong.

2. Merancang dan membuat Sistem Informasi Ujian masuk Perguruan Tinggi dengan Pelayanan One Day Service berbasis Online di Kampus Universitas Muhammadiyah Sorong.

3. Menerapkan sistem informasi Ujian Masuk ke Perguruan Tinggi dengan Pelayanan One Day Service berbasis Online di Universitas Muhammadiyah Sorong.

4. Menerapakan Ilmu yang Penulis peroleh selama belajar di Kampus Univeristas Muhammadiyah Sorong.

\subsection{Batasan Masalah}

Agar pembahasan masalah perancangan sistem pendukung keputusan pada penentuan jurusan untuk calon mahasiswa baru di Kampus Universitas Muhammadiyah Sorong menjadi terarah serta permasalahan yang dihadapi tidak terlalu luas, maka diberikan batasan masalah sebagai berikut:
1. Sistem Informasi ini meliputi pengumpulan data, perancangan, testing dan implementasi .

2. Dalam pembuatan Sistem Informasi ini hanya untuk digunakan pada Ujian masuk Perguruan Tinggi untuk Calon Mahasiswa Baru di Kampus Universitas Muhammadiyah Sorong.

3. Sistem ini membahas ujian online dan hasil nilai dari soal yang telah diujikan dan menampilkan kelulusan peserta dari jurusan yang dipilih sesuai dengan nilai yang diperoleh.

4. Pada ujian online ini hanya digunakan pada tujuh fakultas dan empat belas program studi.

5. Jenis soal yang digunakan berupa soal tes Potensi Akademik berupa soal Umum berupa materi Persamaan kata, lawan kata, logika, padanan hubungan dan deret angka untuk semua program studi. Tes Kemampuan Akademik berupa Soal Eksakta dan Non Eksakta materi soal berupa Bahasa Indonesia, Bahasa Inggris, Matematika, Pendidikan pancasila, IPS dan IPA .

6. Bentuk soal yang digunakan berupa soal Pilihan Ganda.

7. Pembuatan Sistem Informasi ini berbasis online dengan bahasa pemograman PHP, database yang digunakan MySQL.

\section{Landasan Teori}

\subsection{Pengertian Sistem Informasi}

Sistem informasi merupakan suatu kombinasi teratur dari orang-orang, hardware, software, jaringan komunikasi dan sumber daya data yang mengumpulkan, mengubah, dan menyebarkan informasi dalam sebuah organisasi. Didalam buku yang ditulis oleh (Elisabet Yunaeti \& Rita Irviani, 2017)

\subsection{Pengertian Sistem Ujian Online}

Sistem ujian online merupakan sebuah aplikasi sistem ujian atau tes yang dibangun berbasis web sebagai interfacenya (Perkasa, Saputr, \& Fronit, 2015). 2.3 Web

Web adalah layanan internet yang dapat menampilkan grafis dan memiliki kemampuan link yang sangat baik. Web dapat menghubungkan dari sembarang tempat dalam sebuah dokumen atau gambar ke sembarang tempat di dokumen lain. (Bobby Melky Tulangouw, 2011)

\subsection{MySQL}


Database $M y S Q L$ merupakan program database server yang mampu menerima dan mengirimkan data dengan cepat, multi user serta menggunakan perintah standar SQL (Structured Query Language).

$M y S Q L$ merupakan sebuah database server yang free artinya database ini untuk keperluan pribadi atau usaha tanpa harus membeli atau membayar lisensinya. (Antony Susanto \& Henky Susanto, 2013) .

\subsection{PHP (Hypertext Preprocessor)}

PHP dapat disebut juga sebagai Hypertext Preprocessor yang digunakan sebagai bahasa skrip serverside dalam pengembangan web yang dapat disisipkan pada dokumen HTML (Muhamad Son Muarie, 2015).

\subsection{Metode Waterfall}

Waterfall merupakan suatu proses pengembangan perangkat lunak yang berurutan, dimana kemajuan dipandang sebagai terus mengalir ke bawah (seperti air terjun) yang dapat membuat fase-fase perencanaan, pemo

delan, implementasi ,dan pengujian. Berikut ini adalah gambar pengembangan perangkat lunak menggunakan metode waterfall (Sri Hartati \& Ricky Wijaya, 2016) :

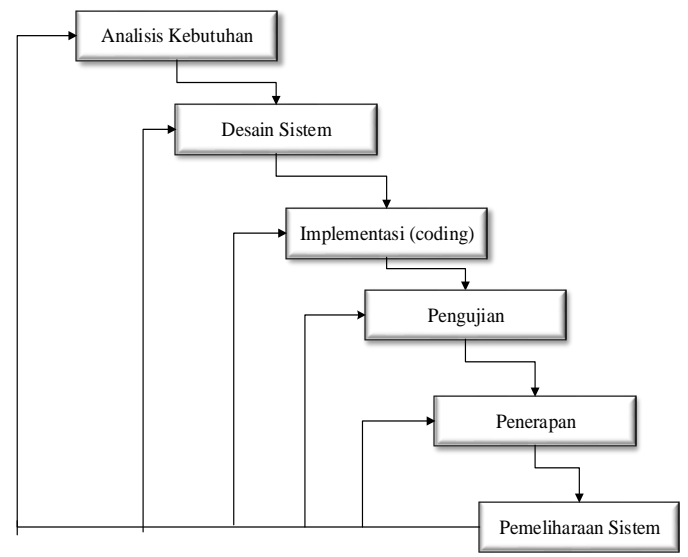

Gambar 2.1 Metode Waterfall Sumber: (Sri Hartati \& Ricky Wijaya, 2016)

\section{Metedologi Penelitian}

\subsection{Lokasi Penelitian}

Lokasi Penelitian dilakukan di Kampus Universitas Muhammadiyah Sorong tepatnya pada bagian Sekretariat Panitia Pendaftaran Mahasiswa Baru yang berlokasi di Jalan Pendidikan No. 27 Malaingkedi.

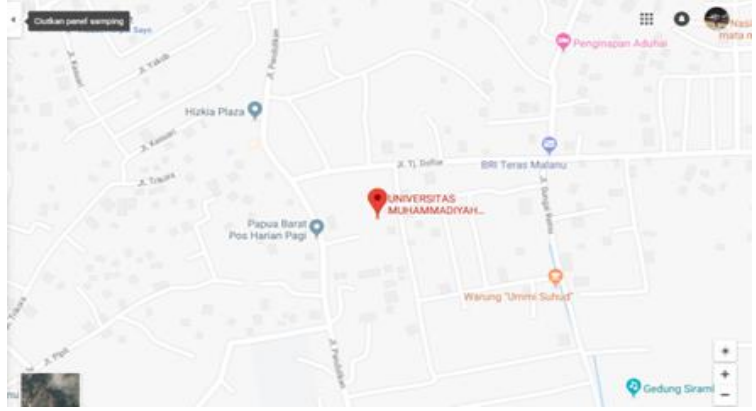

Gambar. 2.2 Peta Lokasi Penelitian Sumber : google Earth

\subsection{Tahapan Penelitian}

1. Wawancara

Wawancara yang dilakukan oleh peneliti yaitu kepada Narasumber bernama Ibu Musna A.A Gafur, SP.,M.Si, selaku Ketua Panitia PMB, Bapak Rendra Soekarta S.Kom,M.T dan juga kepada panitia pelaksana pada Pendaftaran Mahasiswa Baru sampai bagaimana Prosedur dan Soal Ujian Tes Akademik dilakukan bagi Calon Mahasiswa Baru.

\section{Dokumentasi}

Dalam tahapan dokumentasi peneliti mengambil foto berupa bentuk soal-soal Tes Ujian yang digunakan bagi calon Mahasiswa baru.

\section{Observasi}

Observasi yang dilakukan berupa pengamatan dan kegiatan saat panitia PMB melakukan pendaftaran calon mahasiswa baru, pengumpulan berkas-berkas formulir pendaftaran calon mahasiswa baru dan bentuk soal-soal Tes Kemampuan Akademik yang digunakan untuk ujian masuk mahasiswa baru.

\section{Analisa dan Pembahasan 4.1 Analisa kebutuhan}

\section{Analisa Kebutuhan Fungsional}

Berdasarkan hasil penelitian yang dilakukan oleh peneliti yaitu dengan melakukan wawancara, observasi, dokumentasi dan studi pustaka, maka dapat disimpulkan kebutuhan fungsional adalah sebagai berikut :

a. Sistem memiliki dua jenis user yaitu user admin dan user calon mahasiswa, user admin memiliki tanggung jawab terhadap sistem untuk menginputkan data-data soal ujian, merubah, mengedit, menghapus dan menambah, sedangkan user untuk calon mahasiswa bertugas untuk mengerjakan soal ujian. 
b. Sistem yang dibuat hanya dapat diakses oleh panitia yang bertugas pada penyelenggaraan ujian di Universitas Muhammadiyah Sorong, saat melakukan login terhadap sistem.

c. User admin memiliki tugas dalam sistem, antara lain :

1. Menginput, menyimpan, keluar, mengedit, tutup, menghapus dan cetak data soal ujian.

2. Menginput,menyimpan, mengedit, menghapus, pilihan jurusan untuk data calon mahasiswa.

3. Menginput,menyimpan,mengedit, menghapus, keluar untuk data Materi ujian untuk dijadikan soal.

4. Menginput,menyimpan,mengedit,mengaha pus, keluar untuk data pemilihan jurusan .

5. Mencetak hasil ujian calon mahasiswa baru.

6. Merubah password dan login.

d. User biasa memiliki tugas dalam sistem, antara lain :

1. Melakukan Ujian Online .

\section{Analisa Kebutuhan Software}

Kebutuhan perangkat lunak yang digunakan untuk pengembangan sistem ini antara lain:

a. Sistem Operasi Windows $10-64$ bit.

b. Local Server (locallhost) yang di gunakan yaitu XAMPP v3.2.1 sebagai web server dan Mysql Server (database server).

c. Sublme dan Adobe Dreamweaver 8 untuk pengkodean system.

d. Browser yang digunakan:UC Browser, Google Crome dan sejenisnya.

3. Analisis Kebutuhan Hardware

Kebutuhan perangkat keras merupakan kelanjutan dari analisa kebutuhan perangkat lunak dari server, adapun perangkat keras yang digunakan laptop ASUS A455L berikut spesifikasinya:
a. Processor Intel ${ }^{\circledR}$ Core $^{\mathrm{TM}} \mathrm{i} 3-4030 \mathrm{U} \quad \mathrm{CPU}$ @ $1.90 \mathrm{~Hz} 1.90 \mathrm{GHz}$
b. RAM $2.00 \mathrm{~GB}(1.89 \mathrm{~GB}$ usable)
c. System type 64-bit Operating System, x64- based processor.

\subsection{Desain Sistem}

\section{Flowchart Sistem}

Menjelaskan urutan-urutan dari prosedur yang ada dalam sistem dan menunjukan apa yang dikerjakan oleh user.

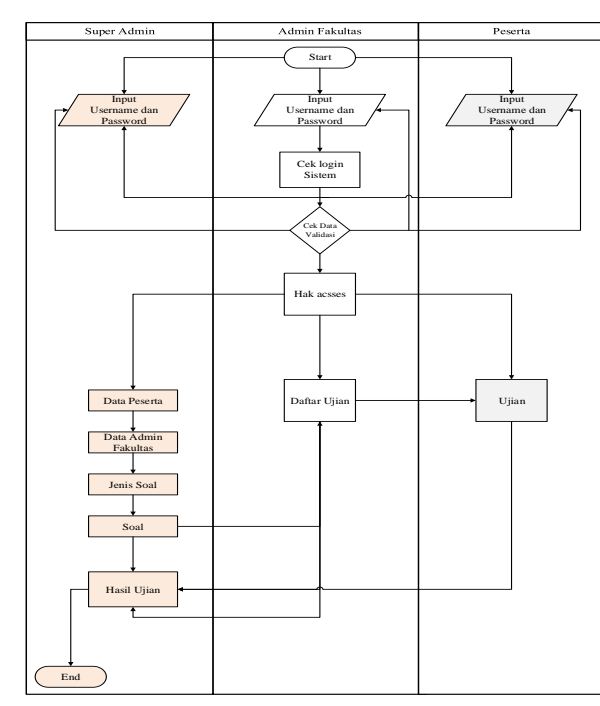

Gambar.4.1 Flowchart Sistem

\subsection{Desain Sistem}

\section{Desain UML}

a. Use Case Diagram

Interaksi user pada sistem ujian online

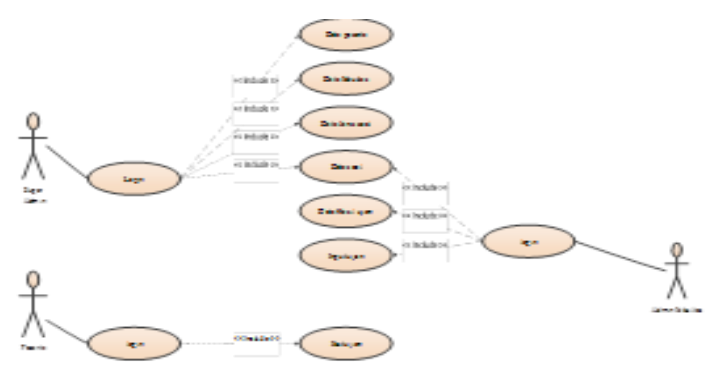

Gambar. 4.2 Use Case Sistem Inventory Gudang.

b. Class Diagram

Class diagram merupakan diagram yang menggambarkan struktur sistem dari pendefinisian kelas-kelas yang akan di buat menjadi sebuah sistem.
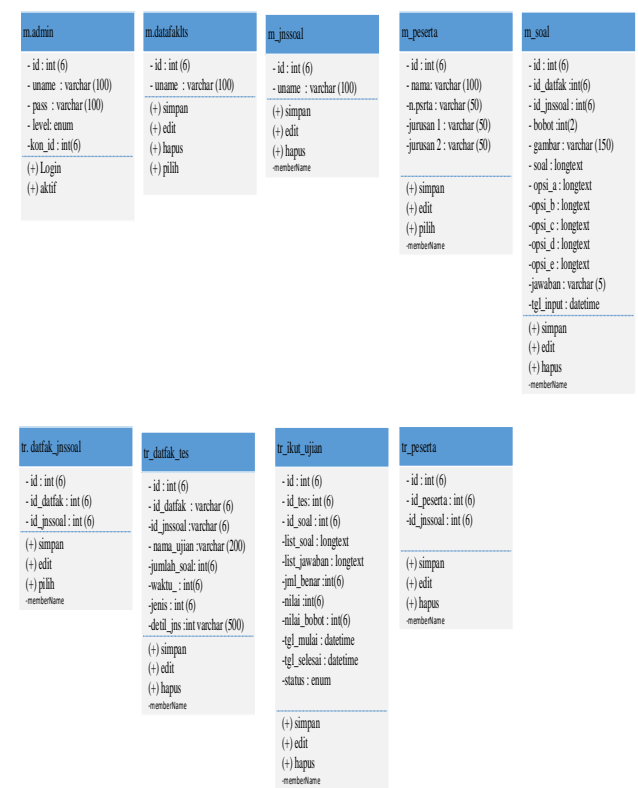
Gambar.4.3 Class Diagram Sistem ujian Online

c. Activity Diagram

1. Activity Diagram Login

Pada actifity diagram login Menggambarkan alur aktifitas user dapat login ke menu utama pada program.

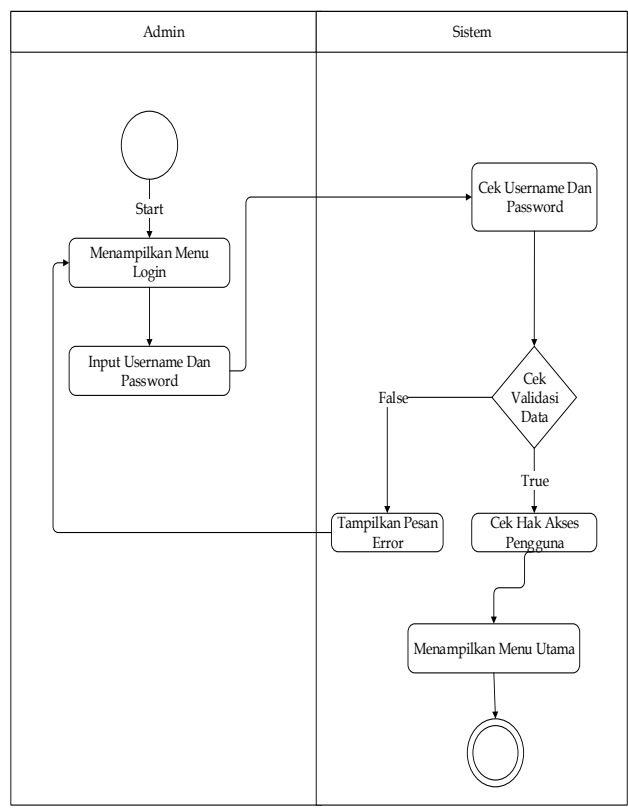

Gambar.4.4 Activity Diagram Login

2. Activity Diagram Input Data

Pada tahap ini menggambarkan aktifitas user yang dapat menambah data sesuai dengan tampilan menu yang dipilih.

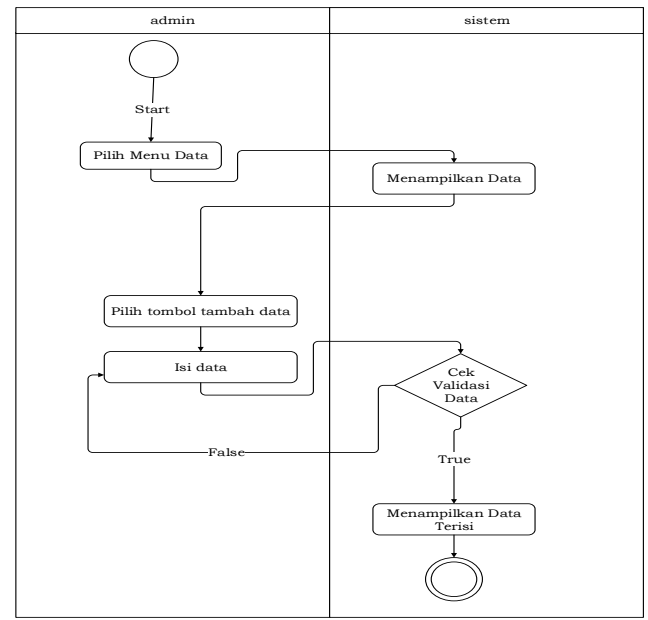

Gambar.4.5 Activity Diagram Lihat Data

3. Activity Diagram Edit Data

Pada tahap ini menggambarkan aktifitas user yang dapat mengubah suatu data sesuai dengan kebutuhan yang diperlukan pada menu yang ada.

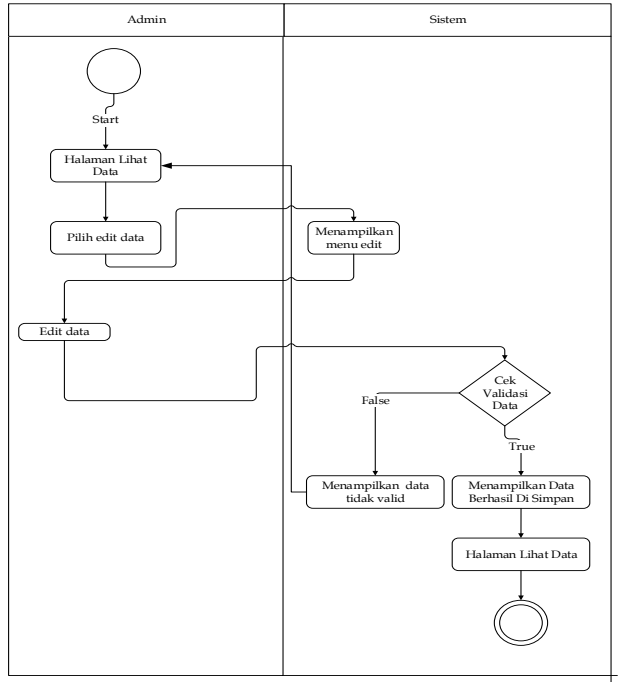

Gambar.4.6 Activity Diagram Edit Data

4. Activity Diagram Menghapus Data Menggambarkan aliran aktifitas user dapat menghapus data sesuai dengan menu data yang dipilih.

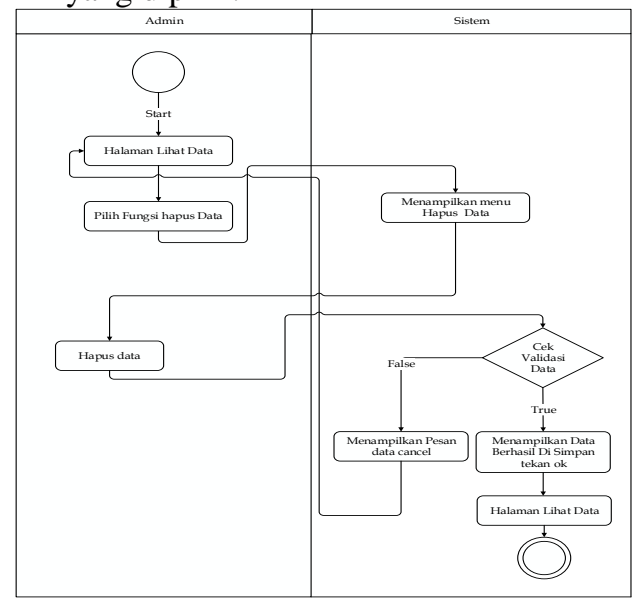

Gambar.4.7 Activity Diagram Hapus Data

\subsection{Implementasi Basis Data}

Implementasi basis data pada sistem ini dibuat menggunakan diagram Entitas Relationship Diagram (ERD) dan digunakan untuk menyimpan setiap data yang akan diinputkan pada sistem Ujian Online masuk Perguruan tinggi dengan Pelayanan One Service berbasis Online. 


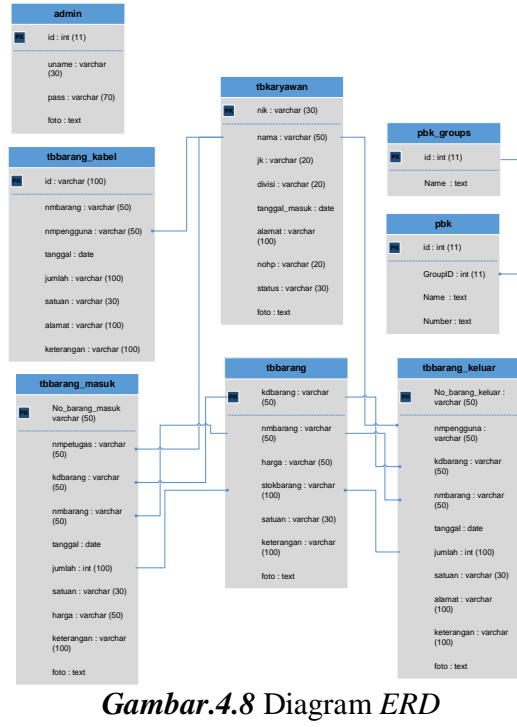

\subsection{Implementasi Interface}

Implementasi interface merupakan tampilan menumenu yang ada pada sistem Ujian Online Perguruan Tinggi dengan Pelayanan One day Service berbasis Online.

1. Tampilan Halaman Login

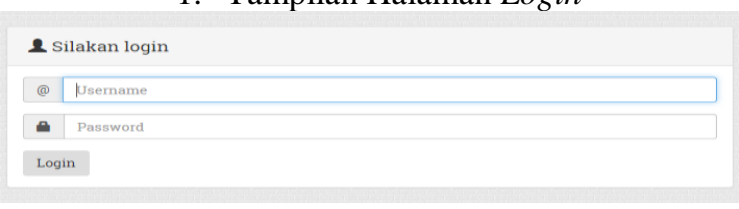

Gambar.4.9 Tampilan Halaman Login

2. Tampilan Halaman Utama

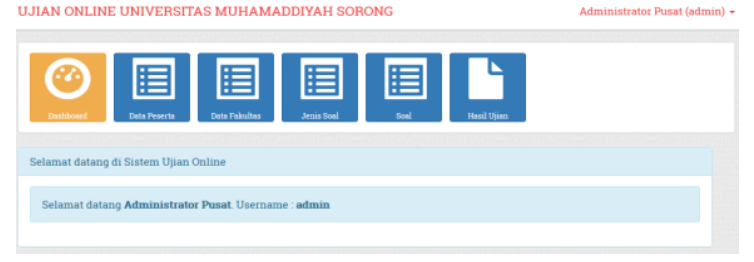

Gambar.4.10 Tampilan Halaman Menu Utama

3. Tampilan Halaman ikut ujian

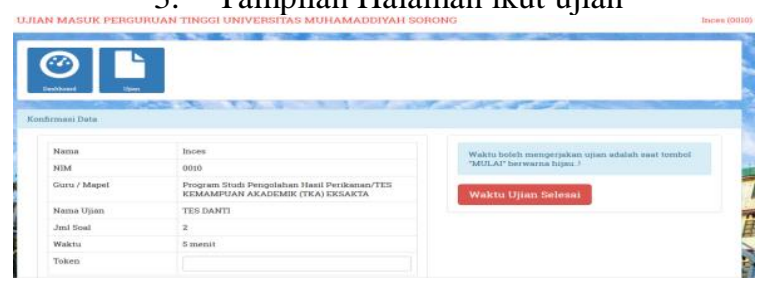

Gambar.4.11 Tampilan Halaman ikut ujian

\subsection{Pengujian sistem}

Pada pengujian sistem informasi ujian masuk perguruan tinggi dengan pelayanan one day service berbasis online (studi kasus di universitas muhammadiyah sorong) dilakukan untuk mengetaui apakah terdapat trouble atau error pada sistem. Pengujian dilakukan dengan menggunakan metode black box yaitu pengujian fungsi-fungsi yang ada pada sistem. Hardware yang digunakan untuk pengujian yaitu komputer sebagai perangkat untuk mengakses sistem tersebut.

\section{PENUTUP}

5.1 Kesimpulan

Berdasarkan hasil penelitian yang telah penulis lakukan, maka penulis dapat menyimpulkna bahwa :

1. Sistem ujian online masuk perguruan tinggi dengan pelayanan One day service berbasis online yang telah di bangun sistem dapat menginputkan data peserta mahasiswa, pembuatan soal, data jenis soal dan hasil ujian.

2. Super admin dapat menerima informasi dari peserta yang telah mengikuti ujian .

\subsection{Saran}

Dari penelitian yang telah dilakukan, maka penulis dapat memberikan saran untuk pengembangan sistem kedepanya yaitu :

1. Diharapkan sistem yang telah dibuat dapat dikembangkan dengan penambahan form yang bermanfaat dan desain yang lebih baik bagi pengguna.

2. Diharapkan sistem ujian masuk perguruan tinggi ini ada keterkaitan dengan Pendaftaran Calon Mahasiswa Baru.

\section{Ucapan Terimakasih}

\section{Bismillahirohmanirohim.}

Assalamu'alaikum warahmatullahi wabarakatuh.

Alhamdulillahirobillamin, Puji Syukur di panjatkan kepada Allah Subhanahu Wa Ta'ala yang melimpahkan segala rahmat, kesehatan dan karuniaNya lah, sehingga penulis dapat menyelesaikan tugas akhir ini. Tugas akhir ini diajukan untuk memenuhi salah satu persyaratan memperoleh gelar sarjana Strata satu (S-1) pada Program Studi Teknik Informatika Universitas Muhammadiyah Sorong.

Penulis mengucapkan banyak terimakasih kepada semua pihak yang telah membantu dalam penyelesaian tugas akhir ini.Ucapan tersebut ditujukan kepada:

1. Allah Subhanahu Wa Ta'ala .

2. Bapak, Ibu tercinta, Kakak dan Adik tersayang dan seluruh Keluarga Besar Penulis yang telah memberikan doa restu, motivasi dan dukungan 
moril dari awal masuk kuliah sampai selesainya penyusunan tugas akhir ini.

3. Bapak Dr.Hj.Hermanto Suaib, MM. selaku Rektor Universitas Muhammadiyah Sorong

4. Bapak Ir.H.Irman Amri ST,.MT, selaku Dekan Fakultas Teknik Sekaligus Dosen Pembimbing II.

5. Bapak Rendra Soekarta ,S.Kom.,M.T selaku Ketua Program Studi Teknik Informatika Universitas Muhammadiyah Sorong.

Akhir kata dari penulis, semoga tugas akhir ini dapat bermanfaat bagi rekan - rekan mahasiswa pada umumnya dan penulis pada khususnya.

Wassallamuallaikum Warahmatullahi Wabarakatuh.

\section{DAFTAR PUSTAKA}

Antony Susanto, \& Henky Susanto. (2013). Perancangan Ujian Online pada STMIK GI MDP. Jurnal Informatika.

Bobby Melky Tulangouw. (2011). Sistem Ujian Berbasis Web. jurnal teknologi dan informatika, vol.1.

Desi Vera Sundawa Putri, Asep Deddy, \& Bunyamin. (2014). Perancangan Aplikasi Media Pembelajaran Pendidikan Lingkungan Hidup untuk Siswa Kelas VI Sekolah Dasar Berbasis Android. Jurnal Algoritma, Vol.11(No.1).

Muhamad Son Muarie. (2015, Maret). Rancang Bangun Sistem Ujian Online pada SMP Negeri 8 Sekayu. Jurnal Teknik Informatika Politeknik Sekayu (TIPS), Vol II(No. 1).

Perkasa, D. A., Saputr, E., \& Fronit, M. (2015, Februari). Sistem Ujian Online Essay dengan Penilaian Menggunakan Metode Latent Sematic Analysis (LSA). Jurnal Rekayasa dan Manajemen Sistem Informasi, Vol.1(No.1).

Rochmawati Daud, \& Valeria Mimosa Windana . (2014, Maret). Pengembangan Sistem Informasi Akuntansi Penjualan dan Penerimaan Kas Berbasis Komputer pada Perusahaan Kecil (Studi Kasus Pada PT.Trust Technology). Jurnal Manajemen dan Bisnis Sriwijaya, Vol.12(No.1).

Safitri, P. K., Winarno, W. W., \& Pramono, E. (2018, Juli). Optimasi Query untuk Sistem Informasi Penjadwalan Mata Pelajaran Sekolah Menggunakan View (Studi Kasus : SMK VIP Purworejo). Jurnal Teknologi Informasi, Vol.XIII(No.2).

Yusdiardi. (2014). Rancang Bangun Sistem Informasi Penjualan (Studi Kasus : PT.I-Cube Creativindo). Sains dan Teknologi.

Soekarta, R. (2015). RANCANG BANGUN SISTEM AKADEMIK BERBASIS WEB (Studi Kasus Universitas Muhammadiyah Sorong).Insect (Informatics and Security) : Jurnal Teknik Informatika, 1)1), 1-8. 